The Review of Politics 83 (2021), 351-374.

(C) The Author(s), 2021. Published by Cambridge University Press on behalf of University of Notre Dame. This is an Open Access article, distributed under the terms of the Creative Commons Attribution licence (http://creativecommons.org/ licenses/by/4.0/), which permits unrestricted re-use, distribution, and reproduction in any medium, provided the original work is properly cited.

doi:10.1017/S0034670521000103

\title{
Disciplining the Rich: Tocqueville on Philanthropy and Privilege
}

\section{Richard Avramenko and Brianne Wolf}

\begin{abstract}
This article inquires into the moral successes and failings of the superrich in America. To do this, we turn to Alexis de Tocqueville who outlines a set of expectations for any privileged elite. Drawing from his Old Regime, Memoir on Pauperism, and Democracy in America, we argue that the superrich are obliged to a particular kind of charity, which we specify as philanthropy. To fulfill their philanthropic duties, the superrich must steadfastly attend to three obligations: maintaining their local communities, safeguarding local liberties, and providing moral leadership. In the conclusion, we suggest how the superrich might be disciplined unto this virtue.
\end{abstract}

\section{The Virtues and Vices of the Superrich}

It would be difficult to find many Americans unfamiliar with the Occupy Wall Street (OWS) movement that dominated the news in the fall of 2011. The OWS protesters denounced the wealthiest 1 percent of Americans, while they themselves represented the aggrieved 99 percent. Wall Street "Banksters," as the 1 percent are often called, came to represent all that was wrong with big business, government absolution of corporate greed, the unholy marriage between banks and government, and so on. Demands were made for "something to be done" to mitigate these massive income inequalities.

Richard Avramenko is professor in the Department of Political Science at the University of Wisconsin-Madison, 201E North Hall, 1050 Bascom Mall, Madison, WI 53703 (avramenko@wisc.edu).

Brianne Wolf is assistant professor of political theory and constitutional democracy at James Madison College at Michigan State University, Case Hall Room S319, 842 Chestnut Road, East Lansing, MI 48825 (briwolf@msu.edu).

Thanks is owed to workshop participants at the UW-Madison and for valuable commentary from Joshua Mitchell, Howard Schweber, Daniel Kapust, Elizabeth Sawyer, Michael Promisel, Marlee Promisel, Thomas Bunting, Noah Stengl, Ethan Alexander-Davey, and Anna Oltman. We are also grateful to the editorial team at the Review of Politics for their professionalism and guidance. 
What began as a protest against the 1 percent developed into an expression of resentment towards economic and cultural inequalities more broadly, arguably giving rise to the 2016 presidential campaigns of both Bernie Sanders and Donald Trump. This backlash against whom Jeffrey Green calls "the superrich" has not been lost on scholars in various disciplines. ${ }^{1}$ Economists have recently turned their attention to this growing economic inequality and it is hardly surprising that Thomas Piketty's Capital in the Twenty-First Century has sold 1.5 million copies. ${ }^{2}$ Even before the OWS, political scientists had focused on the undue influence the rich have in politics, and how this influence allows them to become even richer. ${ }^{3}$ Political theorists are also concerned with the problem of economic inequality in liberal democracies, but focus on the institutional causes and ramifications of this inequality. ${ }^{4}$

While most objections treat the problem of inequality in economic and institutional terms, we assess the issue through a moral-theoretical lens. At stake, we suggest, is not just that the superrich have mountains of money, but that their failings and successes should be measured in terms of the social obligations expected from those with overwhelming economic and political privilege. In other words, the problem can be analyzed in terms of virtue. The purpose of this paper is to question whether the 1 percent realize the virtues appropriate to the most privileged of one's community.

While some political theorists reject the idea of virtue, many agree that at least some virtue is needed in liberal democracies. ${ }^{5}$ Communitarians, conservatives, natural law theorists, and moderate liberals argue that not

${ }^{1}$ Jeffrey E. Green, The Eyes of the People: Democracy in an Age of Spectatorship (Oxford: Oxford University Press, 2010).

2J. E. Stiglitz, The Great Divide: Unequal Societies and What We Can Do about Them (New York: Norton, 2015); Emmanuel Saez and Thomas Piketty, "Inequality in the Long Run," Science 344, no. 6186 (2014): 838-43; Noam Lupu and Jonas Pontusson, "The Structure of Inequality and the Politics of Redistribution," American Political Science Review 105, no. 2 (2011): 316-36; B. Milanovic, The Haves and the Have-Nots: A Brief and Idiosyncratic History of Global Inequality (New York: Basic Books, 2010); T. Piketty, Capital in the Twenty-First Century (Cambridge, MA: Harvard University Press, 2014).

${ }^{3}$ Jacob S. Hacker and Paul Pierson, Winner-Take-All Politics: How Washington Made the Rich Richer-and Turned Its Back on the Middle Class (New York: Simon \& Schuster, 2010); Larry M. Bartels, Unequal Democracy: The Political Economy of the New Gilded Age (Princeton: Princeton University Press, 2009); Jeffrey A. Winters, Oligarchy (Cambridge: Cambridge University Press, 2011); Martin Gilens, Affluence and Influence: Economic Inequality and Political Power in America (Princeton: Princeton University Press, 2012).

${ }^{4}$ Robert Jubb, “The Real Value of Equality," Journal of Politics 77, no. 3 (2015): 679-91.

${ }^{5}$ Rawlsian proceduralists reject the recourse to individual virtues because they point to a summum bonum not shared by all (John Rawls, A Theory of Justice [Cambridge, MA: Belknap Press of Harvard University Press, 1971], 80-86, 93, 347-50). For more on this point, see Bruce Ackerman, Social Justice and the Liberal State (New Haven, CT: Yale University Press, 1980). Such claims of liberal neutrality are not limited to the political left. For example, see Michael Oakeshott, On Human Conduct (Oxford: 
only is it necessary to consider virtues, but we have an obligation to foster them. ${ }^{6}$ If anything unifies these views regarding virtue, it is that little effort has been made to differentiate virtues in terms of class. Generally, those who speak of virtue tend to conflate liberal virtues with middle-class virtues. ${ }^{7}$ In other words, despite the recognition of socioeconomic classes, most modern political theorists either ignore or refuse to admit that a set of virtues might be more or less appropriate for different classes.

Recently, however, scholars have suggested that different classes ought to aspire to different virtues, or at least different degrees of the same virtue. Richard Avramenko and Richard Boyd, for example, have argued that a set of virtues ought to be cultivated among the middle class - the so-called subprime virtues - which can be done by tweaking federal mortgage and housing policy. ${ }^{8}$ Deirdre McCloskey, calling them bourgeois virtues, lauds virtues specific to the middle class. ${ }^{9}$ Some educators, suggesting the poor

Clarendon, 1975), 111-30; Friedrich A. Hayek, Law, Legislation, and Liberty, vol. 1, Rules and Order (London: Routledge \& Kegan Paul, 1973).

${ }^{6}$ Communitarians like Sandel and Taylor reject the idea that liberal community thrives without a relational vision of the good. See Michael J. Sandel, Liberalism and the Limits of Justice (Cambridge: Cambridge University Press, 1982); Charles Taylor, Sources of the Self: The Making of the Modern Identity (Cambridge, MA: Harvard University Press, 1989), esp. part 1. Natural law theorists such as MacIntyre and George argue that the nature of human beings requires the state to engage in perfectionism. See Alasdair MacIntyre, After Virtue (Notre Dame: University of Notre Dame Press, 1981); Robert P. George, Making Men Moral: Civil Liberties and Public Morality (Oxford: Oxford University Press, 1993). Moderate liberals like Macedo and Galston argue that the character of citizens has always been an issue in liberal polities. See Stephen Macedo, Liberal Virtues: Citizenship, Virtue, and Community in Liberal Constitutionalism (Oxford: Oxford University Press, 1991); William Galston, Liberal Purposes (Cambridge: Cambridge University Press, 1991). Even contemporary republican theorists like Skinner and Pettit call for a measure of civic virtue to keep societies free from domination. See Quentin Skinner, Liberty before Liberalism (Cambridge: Cambridge University Press, 1998); Philip Pettit, Republicanism: A Theory of Freedom and Government (Oxford: Oxford University Press, 1997).

${ }^{7}$ Galston argues that public policy reflects a constellation of virtues; liberal states either affirm or ignore certain moral purposes with every new tax or law. Public education, tax policy, and legislation can and ought to foster basic "liberal virtues." For Galston, however, the liberal virtues are mostly middle class: independence, tolerance, work ethic, delay of gratification, adaptability, discernment, moderation, patience, empathy, resolve, and practical wisdom (Liberal Purposes, 270).

${ }^{8}$ Richard Avramenko and Richard Boyd, "Subprime Virtues: The Moral Dimensions of American Housing and Mortgage Policy," Perspectives on Politics 11, no. 1 (2013): 111-31.

${ }^{9} \mathrm{McCloskey} \mathrm{catalogues} \mathrm{these} \mathrm{as} \mathrm{"love,} \mathrm{faith,} \mathrm{hope,} \mathrm{courage,} \mathrm{temperance,} \mathrm{prudence,}$ and justice" (The Bourgeois Virtues: Ethics for an Age of Commerce [Chicago: University of 
are a class with particular challenges, have resurrected "character education" for primary education. ${ }^{10}$ In Disciplining the Poor, Joe Soss et al. argue against the imposition of these middle-class virtues on the poor. ${ }^{11}$

If there are virtues appropriate to the middle class, and virtues more or less appropriate to the poor, what can we say about the most privileged? Both the popular press and scholarship seem to focus on the vices of the superrich. They are, if we listen to protesters, greedy, selfish, and rapacious, and if we take Green seriously, they need to be "disciplined." The question, then, is: Disciplined towards what? Is it possible to identify a set of virtues towards which they might be disciplined? Our argument is not that middle class virtues are irrelevant to the elite-one certainly expects a general level of tolerance, work ethic, adaptability, moderation, patience, and practical wisdom from them - but it is absurd to argue that the superrich need remedial lessons in frugality. While frugality is necessary both to enter and to stay in the middle class, it is simply not germane to the elite. The central argument of this paper is that there is, in fact, a virtue that takes on a distinct appearance, scope, and end when exercised by those with political and economic privilege. This virtue is philanthropy.

Our argument proceeds as follows. In the next section, we will provide a working definition of philanthropy and especially how it is to be distinguished from charity. In section 3, we will introduce Alexis de Tocqueville as a thinker who thought deeply about the virtues of the elite, especially in his recollections of feudal France-a France in which he suggests the elite wedded power and responsibility into what we are describing as philanthropy. This "functional feudalism," as we will call it, is, for Tocqueville, meant to be instructive. As he recalls in The Old Regime and the French Revolution, the French nobility once had a "duty to lead, to protect, to help their vassals." 12 Or, as we will put it, the elite fulfilled the three central obligations of philanthropy: (1) moral leadership, (2) safeguarding local liberties, and (3) the maintenance and improvement of the local community (roads, schools, festivals, churches, etc.). These three measures, we suggest, constitute a moral metric for philanthropy - a metric that takes its bearings from Tocqueville's commitment to human freedom. In the next section, we outline Tocqueville's vision of the

Chicago Press, 2006], 312). Charles Murray argues the poor are deficient in middleclass virtues: industriousness, honesty, marriage, and religiosity (Coming Apart: The State of White America, 1960-2010 [New York: Crown Forum, 2012], 127).

${ }^{10}$ See, for example, W. J. Bennett, Book of Virtues (New York: Simon \& Schuster, 1993); Paul Tough, How Children Succeed: Grit, Curiosity, and the Hidden Power of Character (Boston: Houghton Mifflin Harcourt, 2012).

${ }^{11}$ Joe Soss, Richard C. Fording, and Sanford Schram, Disciplining the Poor: Neoliberal Paternalism and the Persistent Power of Race (Chicago: University of Chicago Press, 2011).

${ }^{12}$ Alexis de Tocqueville, The Old Regime and the French Revolution, trans. Alan S. Kahan (Chicago: University of Chicago Press, 1998), 1:191. Hereafter OR. 
dissolution of this functional feudalism. With "dysfunctional feudalism," we explore an elite whose power was disconnected from responsibility, and the problem Tocqueville saw with the effort to replace this virtue with a centralized "administrative aristocracy," both in France and England.

In section 4, we bring these insights to bear on Tocqueville's concern with the democratic experiment in America by asking whether an industrial aristocracy can engender philanthropy. We suggest that because this new type of elite is not a class properly understood, the challenge for transforming self-interest into the kind of philanthropy Tocqueville envisions is difficult, but not impossible. We conclude by considering the superrich today. We suggest that the doctrine that joined privilege to responsibility on the part of the feudal aristocracy has fallen by the wayside; that although charitable giving in America is unparalleled in the rest of the world, it rarely follows the principles we glean from Tocqueville. And finally, we raise briefly the possibility that just as public policy can nudge average citizens towards certain virtues, it can also nudge the superrich towards philanthropy, rightly understood.

\section{Charity and Philanthropy}

Philosophers have long given serious consideration to the relationship between elites and virtue. Plato, Montesquieu, and Burke come readily to mind, as do Boulainvilliers and Bolingbroke. It is Alexis de Tocqueville, however, who foregrounds this concern for democratic times. Most readers of Tocqueville assume that when he is thinking about aristocratic virtues he has in mind honor, ${ }^{13}$ courage, ${ }^{14}$ or even devotion. ${ }^{15}$ While this is true, these scholars overlook that Tocqueville consistently gestures towards charity.

Several scholars have recognized the importance of charity in Tocqueville's thought but, generally speaking, the concept is bound up with his concern for economic and social reform, especially as it emerged from his experience with American Unitarianism and the economic thought of VilleneuveBargemont. ${ }^{16}$ Some scholars suggest that Tocqueville eventually became pessimistic about social reform and charity, be it elite, middle, or lower

\footnotetext{
${ }^{13}$ Sharon R. Krause, Liberalism with Honor (Cambridge, MA: Harvard University Press, 2002).

${ }^{14}$ Richard Avramenko, Courage: The Politics of Life and Limb (Notre Dame: University of Notre Dame Press, 2011); Noah Stengl, "Tocqueville in the Wilderness: The Tragedy of Aristocracy in the Democratic Age," Political Science Reviewer 42, no. 1 (2018): 34-61.

${ }^{15}$ Dana Jalbert Stauffer, "Tocqueville on the Modern Moral Situation: Democracy and the Decline of Devotion," American Political Science Review 108, no. 4 (2014): 772-82.

${ }^{16}$ Richard Swedberg, Tocqueville's Political Economy (Princeton: Princeton University Press, 2009); Michael Drolet, Tocqueville, Democracy and Social Reform (Basingstoke: Palgrave Macmillan, 2003); Drolet, “Democracy and Political Economy: Tocqueville's
} 
class. ${ }^{17}$ Our reading of Tocqueville's Old Regime, Memoir on Pauperism, and Democracy in America finds less pessimism. By disaggregating charity from his discussion of social reform, we foreground the importance of charity as the central virtue for any decent polity. We do this by outlining the kind of charity particular to those with overwhelming economic and political power, which we distinguish as philanthropy.

In his Memoir on Pauperism, Tocqueville provides his clearest definition of charity. To be charitable, he tells us, is to alleviate evil and suffering among one's neighbors. ${ }^{18}$ Charity, along with faith and hope, is one of the three theological virtues of Christianity and Tocqueville was no doubt aware of this. As a Catholic from a noble family, Tocqueville would have considered it incumbent on all people to be charitable towards their neighbors. The virtue, however, pertains differently to different people because, as Tocqueville adds to his definition, one is to be charitable "according to one's means" $(M P, 25)$. In other words, charity makes more demands on the privileged because they have more means, both financial and personal. We therefore make a definitional distinction between charity as it pertains to all people and charity as it pertains to the privileged elite. For people in general, we will refer to the virtue as charity; for the most privileged, we will use "philanthropy."

"Philanthropy" literally means "loving humanity" or "friend of humanity." It is an old word, coming down to us from Aeschylus's Prometheus Bound. Prometheus, we should recall, was a Titan who sided with Zeus in the Titanomachy. After Zeus's victory, Prometheus disagreed with the plan to destroy the human race. He thus stole fire from Hephaestus and gave it to human beings. For this transgression, he was chained to a rocky crag in the Caucasus, his liver devoured daily by an eagle. ${ }^{19}$ Philanthropy, then, is best understood in terms of its scope. Whatever Prometheus's motivation, there is a grandness to his gift that makes it distinct from, say, a few coins for a pauper. If we bear in mind that Prometheus's benefaction included architecture, astronomy, mathematics, writing, agriculture, navigation, medicine, and metallurgy, his philanthropy loaned itself to the improvement of

Thoughts on J.-B. Say and T. R. Malthus," History of European Ideas 29, no. 2 (2003): $159-81$.

${ }^{17}$ Seymour Drescher, "Tocqueville's Two Démocraties," Journal of the History of Ideas 25, no. 2 (1964): 201-16; Drescher, Tocqueville and Beaumont on Social Reform (New York: Harper and Row, 1968); Jean-Claude Lamberti, Tocqueville and the Two Democracies (Cambridge, MA: Harvard University Press, 1989); Aurelian Craiutu and Jeremy Jennings, "The Third Democracy: Tocqueville's Views of America after 1840," American Political Science Review 98, no. 3 (2004): 391-404.

${ }^{18}$ Alexis de Tocqueville, Memoir on Pauperism, trans. Seymour Drescher (Chicago: Dee, 1997), 25-26. Hereafter MP.

${ }^{19}$ Aeschylus, Prometheus Bound, trans. Robert Whitelaw (Oxford: Clarendon, 1907), 1. 
mankind not just in the present, but also over time. Thus, while the nature of charity remains the same for the average citizen and a billionaire-both, for example, can alleviate suffering in the here and now by buying a meal for a homeless person-there is a threshold of resource and power that, brought to bear philanthropically, effects broad social change over time. As Emma Saunders-Hastings puts it, philanthropists "use their money to influence social and political outcomes... [and this] specifies what is distinctive about elite philanthropy, compared to donations by ordinary citizens: the degree of influence and the sustained control that wealthy donors are able to exercise through their gifts." ${ }^{20}$ Buying a meal and endowing a university, for example, both require the giving of one's resources, but the degree of these charitable acts is so different that they differ in kind. ${ }^{21}$ The former is charity; the later is philanthropy. In what follows, then, we invoke Tocqueville to provide a metric for assessing the philanthropic efforts of the most privileged.

\section{Tocqueville and the Feudal Aristocracy}

\section{Functional Feudalism}

In Tocqueville's account of feudal France, power and responsibility were inseparable for the nobility. As he imagines it, in thirteenth-century France there was a "sublime conception of the duties of man" that informed the public actions of the nobility. ${ }^{22}$ His reflections may well harbor "romantic

${ }^{20}$ Emma Saunders-Hastings, "Plutocratic Philanthropy," Journal of Politics 80, no. 1 (2017): 150. Saunders-Hastings, however, explicitly steers away from assessing elite philanthropy through a moral-theoretical lens, as we do here. Instead, she argues that we must "think about philanthropy politically, and not just ethically" (151, 152). This move allows her to assess elite philanthropy in terms of how the law and the tax code fail to steer philanthropy to her own ethical and political commitments. For precisely the same reasons, Robert Reich, Just Giving: Why Philanthropy Is Failing Democracy and How It Can Do Better (Princeton: Princeton University Press, 2018), rejects the distinction between charity and philanthropy. As he puts it, elite philanthropists "have significantly more politically conservative preferences than average citizens" (158), and he therefore refuses to assess the virtue of individuals giving money. In his words, "I hope it is clear that I mean to shift attention away from private morality, away from straightforward ethical assessments of the decisions that individuals make about whether to give away money or property, and to whom, and how much. I mean instead to explore the public morality of giving" (15).

${ }^{21}$ In assessing the philanthropy of the superrich as individuals, we follow the lead of Peter Singer in "What Should a Billionaire Give-and What Should You?," New York Times Magazine, Dec. 17, 2006.

${ }^{22}$ Alexis de Tocqueville, Democracy in America, trans. George Lawrence (New York: HarperPerennial, 1969), 525. Hereafter DA. This is also how Furet describes 
longings" for a France that never existed, as Cheryl Welch suggests, but his purpose seems clear. ${ }^{23}$ As with Democracy in America, his Old Regime and the Revolution can be regarded as instructive for the elite in France, be they the remnant of the nobility, the new bourgeoisie, or the progeny of revolutionaries. To instruct, he holds up the ancient elite as an exemplar of power conjoined with responsibility. In what might be called a functional feudal moment, he begins with a rather laudatory description of the elite. For example, "In reading its cahiers," he says, "one feels, amidst and beyond their prejudices, the spirit and some of the great qualities of aristocracy" $(O R, 173)$. In the nobility of the Old Regime, he tells us, one finds "a class which led for centuries [and] had acquired, during that long, uncontested experience of greatness, a certain pride of heart, a natural confidence in its strength, a habit of being respected, which made it into the most resistant part of the social body. It not only had manly mores, it increased the virility of the other classes by its example" $(O R, 173)$. The ruling class had a certain set of codes and virtues that not only maintained and confirmed their positions of leadership, but also inspired others $(D A, 573)$. They were, as we put it, the moral leaders of their communities.

In this functional feudal moment, Tocqueville suggests that the privileged elite served the community in two further ways. First, they preserved local liberties vis-à-vis the central power of the state. Local lords were "the king's representative in the parish" and functioned as an "intermediary between the king and its inhabitants" (OR, 114). If virile and virtuous, they would oppose encroachments on local liberties. For example, the local lords could shield their parish from arbitrary taxes levied by the crown. It is when they failed in this obligation that new "oppressions" could be levied, which is what happened, Tocqueville says, beginning in the fifteenth century: "Could all these new oppressions have been established if they had found rich and educated men alongside the peasants who had the desire and the power, if not to defend the peasants, at least to intercede for them with their common master, who already held in his hands the fortune of rich and poor?" (OR, 187-88). For Tocqueville, then, a central obligation of the privileged elite is to safeguard the weak from oppression, especially oppression from abstract and centralized power-an obligation the French nobility regarded as sacred. Indeed, as Richard Swedberg notes, even if fulfilling this responsibility served their own interests, it simultaneously served the local parish. ${ }^{24}$

Tocqueville's account of the nobility. François Furet, Interpreting the French Revolution (Cambridge: Cambridge University Press, 1981), 139.

${ }^{23}$ C. B. Welch, De Tocqueville (Oxford: Oxford University Press, 2001), 42.

${ }^{24}$ Richard Swedberg, Tocqueville's Political Economy (Princeton: Princeton University Press, 2009), disagrees with Furet's view that Tocqueville was not realistic in his account of the nobility. He argues Tocqueville realized that the nobility helped their communities because it was in their interest (255-56). 
The second service was the maintenance of the parish itself and the welfare of the people therein. This included caring for the poor, but Tocqueville also provides a summary of duties incumbent on any ruling elite. An eighteenthcentury intendant, for example, was charged with the duties that formerly fell to the local lord. These authorities, Tocqueville says, were

to divide the taxes, repair churches, build schools, convoke and preside over the parish assembly. They supervised the common lands and regulated their use, brought and defended lawsuits in the name of the community... . [They were] charged with applying the laws of the state, with assembling the militia and levying the taxes, making known the commands of the prince and distributing his aid in time of need. $(O R, 114)$

These obligations are not abstract-they are not removed or disconnected in either their aim or their place. In other words, the local elite got their hands dirty with real people and actual administration. Ownership of land and the privilege it bestowed was bound up with service to a particular people in a particular place at a particular time. As Tocqueville puts it, "the ownership of the land and the government of its inhabitants were still linked" (OR, 114). Or, even more simply, the privileges of the elite were inseparable from their obligations to their particular and local world.

We locate the foundation of Tocqueville's view of philanthropy in this period. For Tocqueville, we might surmise that a political system in which the elite provide leadership, protect local liberties, and attend to the practical needs of the parish is a functional system. The elite, with their privilege and power, served and protected the less powerful and least advantaged, and in doing so, also protected themselves and their position. The least advantaged, on the other hand, with their needs realized by the elite, harbored no envy towards privilege. In fact, for Tocqueville, the general view of the nobility was benign. As he explains: "In the feudal era, we looked at the nobility in more or less the same way as we regard the government today; one bore the burdens it imposed in consideration of the guarantees that it offered. The nobles had offensive privileges, they possessed burdensome rights, but they assured public order, dispensed justice, executed the law, came to the help of the weak, and ran public affairs" (OR, 117). Put otherwise, the elite had privilege and power, but these did not arouse envy because they were used well-the elite fulfilled their charitable obligations to the people who lived there, to the buildings in which they worshiped, to the roads on which they traveled, and to the hospitals in which they convalesced.

In sum, Tocqueville presents this vision of functional feudalism as instructive about the responsibilities incumbent on a privileged elite. Whether the French nobility ever wedded power and responsibility for altruistic reasons is secondary to his point. If the nobility served their local parish because God demanded it, because they feared going to hell, or because it protected their own power and privilege, the lesson remains: to act virtuously, those with overwhelming privilege must serve according to their means. Further, 
Tocqueville's reflections suggest a concrete set of obligations: (1) moral leadership, (2) safeguarding local liberties, and (3) the maintenance and improvement of one's local community.

\section{Dysfunctional Feudalism}

In a thriving aristocracy, then, the elite have extra privileges and rights. The problem, however, arises when these privileges are unaccompanied by the obligations that go with them. As Tocqueville puts it, "to the extent that the nobility ceased to do these things, the weight of its privileges seemed heavier, and finally their very existence seemed incomprehensible" $(O R, 117)$. In other words, power is not onerous when it is philanthropic. However, when power and responsibility are separated, feudalism becomes dysfunctional. This separation lies at the heart of Tocqueville's account of the French Revolution. Like the seven-hundred-year growth of equality Tocqueville describes in the opening pages of Democracy in America, The Old Regime and the Revolution recounts a seven-hundred-year erosion of the virtue of the elite-and with it the functional feudal system.

Tocqueville describes this provocative position in an essay he wrote for John Stuart Mill's journal in 1836. Through the eighteenth century and leading up to the Revolution, he says, "The French nobles had preserved a certain number of exclusive rights, which distinguished them from, and raised them above, the rest of the citizens; but it was easy to discover that among the privileges of their fathers, the French noblesse had only retained those which make aristocracies hated, and not those which cause them to be respected or beloved." ${ }^{25}$ For Tocqueville, then, leading up to the Revolution, the nobility were less likely to fulfill their duties to their parish and to the poor therein. At the same time, they maintained the privileges they enjoyed when ownership of land was linked to governance, such as exclusive hunting rights, taxing fairs and markets, and taxes on property sales $(O R, 115)$. This disconnect was exacerbated by the fact that they retained the visible, ceremonial trappings of power or, in his words, the "semblance of power." No longer fulfilling their obligations, they retained "a vast number of purely honorary distinctions, such as titles, order of precedence in public, and the privilege of adopting a certain costume, and wearing certain arms" (PSCF, 144). That the nobility now provoked ill-will, envy, and even hatred, as evidenced by the events of the Revolution, is hardly surprising, and certainly deserved. To flaunt privilege and vice simultaneously cannot do otherwise.

Compounding this schism was the fact that the peasants themselves were becoming small landowners. As such, the taxes once levied against the seignorial manor fell to them. When such taxes were applied to land not owned by

\footnotetext{
${ }^{25}$ Alexis de Tocqueville, "The Political and Social Condition of France," London and Westminster Review 3 \& 25 (1836): 143. Hereafter PSCF.
} 
them, they aroused no resentment and hatred - after all, "what does the tax on land mean to someone who has none?" (OR, 116). However, when farms are owned by the peasant everything changes. Real property, ownership of the land, changes the peasant to his core: "Finally, he owns it; he puts his heart into it with his seed. That little piece of dirt that belongs to him in this vast universe fills him with pride and independence" $(O R, 117)$. The problem, however, is that the institutions of the feudal world did not evolve with this transfiguration begotten by small proprietorship. Tocqueville's description is vivid. Despite owning his little piece of land,

there remains the same neighbors who tear him from his fields and force him to work elsewhere without pay. If he wants to defend his crops against their game, these men forbid it; the same men wait for him at the ford to demand a toll. There they are again at the market, where they sell him the right to sell his own crops; and when he returns home, and wants to use what remains of his wheat for himself, the wealth that has grown under his eyes and by his hands, he cannot do so without having it milled in the mill and baked in the oven of these same men. Part of the income of his little property must be used to pay their fees, and these fees are permanent and irredeemable. $(O R, 117)$

Rather than living with and being cared for by the feudal lord, the peasant found himself paying for the privileges and rights of the lord with no services in return. For the new class of small property owners, this condition was untenable. The failure of the noblesse amounted to taxation without representation and without services.

Thus whereas the nobility had been responsible for safeguarding, funding, and facilitating community life, these fiduciary responsibilities shifted to the poor in the form of taxes (e.g., the hated taille and corvée). The nobles, losing their land to small land-holders and their powers to the authority of the king, also began to forget the philanthropy that for centuries bound them to parish life. The king simply did not foresee that centralizing power-or, as Tocqueville puts it, "liberating" the land-would also liberate the nobility from their duties and responsibilities. That said, if the services that were once rendered by the noblesse locally had been adequately picked up by the central authority, the new situation would probably have been tenable to the new small land-holders. This, however, is not how Tocqueville's historical drama unfolds.

\section{Administrative Aristocracy}

\section{Administrative Dysfunction in France}

To centralize the administration of the local parishes, new authorities had to be hired or elected. In place of the landed nobility, Tocqueville describes the emergence of what we will call an "administrative aristocracy." The 
administrators in this bureaucracy were mostly drawn from the emerging bourgeoisie, though members of the noblesse jockeyed for positions as well. For Tocqueville, these administrators did indeed resemble something of a class because of their shared sentiments, habits, and way of thinking. As he puts it, "the bureaucracy, almost all bourgeois, already formed a class with its own character, its own traditions, virtues, honors, its own pride. It was the aristocracy of the new society, which was already alive and formed: it was only waiting for the Revolution to make room for it" $(O R, 139)$. For Tocqueville, however, a centralized administration is bound to fail, philanthropically speaking, because it lacks the local knowledge, the historical memory, and the embodied connections that gave rise to the philanthropy of the noblesse. In other words, while they formed a class with their own set of virtues, they lacked the virtues appropriate to a ruling elite.

Instead, as Tocqueville laments, local needs were not only unfulfilled, they were hindered. His description is telling:

In order to run everything from Paris, and know everything there, it was necessary to invent a thousand new means of control. The paperwork was already enormous, and official procedure was so slow that I have noticed that it always took at least a year for a parish to obtain authorization to rebuild its bell-tower or repair its rectory; usually two or three years passed before the request was granted. $(O R, 138)$

The failings of the administrative aristocracy, however, were not merely technical. The root of the problem was that this new ruling elite lived neither among nor with the people in the local parish. Their separation from the parish and ownership of land therein meant that they could not muster the same kind of concern for the poor as the old nobility. Or, as we claim, the new aristocracy functioned under abstract principles of charity. No longer were the individuals administering charity connected to actual people and to actual families on the same land over many generations. With the new administrative aristocracy, people were administered, but not cared for. By way of example, Tocqueville recounts how a centralized administration dealt with the poor:

The villages were infested with beggars... . Occasionally these unfortunates were proceeded against with great violence. In 1767, the duc de Choiseul wanted to get rid of begging in France at a single stroke. We can see in the intendants' correspondence how harshly he acted. The mounted police were ordered to arrest at one blow all the beggars to be found in the kingdom; we are told that more than fifty thousand were seized. The real criminals were to be sent to the galleys; for the rest, more than forty almshouses were opened to receive them. $(O R, 188)$

Choiseul-from a noble family in Lorraine-spent his adult life jockeying for power, prestige, and administrative positions in Paris and Versailles. He is thus emblematic for Tocqueville of power and privilege without appropriate virtue. From his position in the French administrative apparatus, Choiseul 
could efficiently "administer," all over France, but there was no philanthropy, no connection to his fellow human beings. ${ }^{26}$ To act with such violence is nothing if not uncharitable. One might speculate that for Tocqueville, rather than create a centralized administrative aristocracy abstracted both spatially and temporally from their neighbors, "it would have been better to reopen the hearts of the rich" $(O R, 188)$.

It is precisely because the centralized administrative aristocracy was abstracted from the people and places being administered that it failed to incorporate effectively the useful parts of the old noblesse. The noblesse, who had lived on a particular estate for centuries, had their fates bound up with the peasants living on and caring for that same property. It might be argued that this mutual care for a shared piece of land was crucial for fostering meaningful bonds between lord and peasant. However, when leaders are removed from the people-or, one might even say, abstracted from the land the relationship to others on that land also becomes abstract. In other words, sentiment and mutual care are rooted in the land, in the shared space and history of a particular place. With the new administrative aristocracy, however, these "bonds of affection," as Tocqueville calls them, are uprooted from their rooted origins $(D A, 320,507)$. Tocqueville puts this idea in terms of sympathy and interest:

In the countryside there remained hardly any but the noble whose wealth was too little to let him leave. That kind of person found himself in a position toward his neighbors, the peasants, where never a rich landowner was to be seen, I think. No longer their leader, he no longer had the interest which he formerly had had to get along with them, to help them, to lead them; and, on the other hand, not being burdened with the same public expenses as they, he could not feel very much sympathy with their misery, in which he did not share, nor associate himself with their grievances, which were foreign to him. These people were no longer his subjects, and he was not yet their fellow citizen: a fact unique in history. $(O R, 180)$

Extracted from the governance and leadership that had for so long been inseparable from his estate, the noble no longer experienced charitable affections toward the poor. While the legal conditions between the nobility and the peasantry had become more equal, the nobility still held a place apart from the rest. The connection between the elite and the poor-flowing from the land and a shared history - finds no cognate in an administrative aristocracy;

\footnotetext{
${ }^{26}$ Robert T. Gannett Jr. argues that Tocqueville's archival study suggested the development of a "welfare state" in response to food shortages, which fostered violence because there were no intermediaries between the central government and the people. Robert T. Gannett Jr., Tocqueville Unveiled: The Historian and His Sources for "The Old Regime and the Revolution" (Chicago: University of Chicago Press, 2003), 84-85.
} 
without this concrete basis for fellow feeling, it is rare that philanthropy will find purchase in an administrative aristocracy.

Abstracted from the land and thus indifferent to the lower classes, the nobility also prevented the administrative aristocracy from taking firm root. Tocqueville again describes the situation in terms of the continued difference of the noblesse: "The lord no longer governed; but his presence in the parish and his privileges prevented a good parish government from establishing itself in place of his. An individual so different from all the others, so independent, so favored, destroys or weakens the rule of law" $(O R, 130)$. Once the lords were disconnected from their obligations, they were also released from the virtue that benefited the parish; absent this virtue, vices emerged that prevented the parish from thriving. Of course, one might argue that preventing a centralized administration from taking root was a kind of protection of local liberty, but absent their own administration and leadership, local life and liberty were not fostered, but constrained by an excess of administrative rules, if not violently crushed, as with the example of the duc de Choiseul.

Yet again, the failure of the administrative aristocracy is not just a problem of efficiency. A centralized administration cannot be philanthropic, rightly understood. Perhaps more important than delaying the repairs of bell towers and failing to incorporate the noblesse, this new aristocracy failed to create the force that links people together in a free society. In other words, the administrative aristocracy necessarily discouraged fellow-feeling-that force that moves people to charity. They did this by preventing local associations and organizations from filling the vacuum left by the nobility. As Tocqueville argues:

\begin{abstract}
Already what characterized government in France was the violent hatred which the government felt for all those outside it, noble or bourgeois, who wanted to concern themselves with public affairs. The smallest independent body which seemed to want to come into being without its permission frightened the government; the tiniest free association, whatever its object disturbed it; it only allowed those which it had arbitrarily created and governed to exist. It disliked even the great trade guilds themselves; in a word, it disliked interference by citizens in any way in the examination of their own business; the government preferred sterility to competition. $(O R, 140-41)$
\end{abstract}

The point is clear: whereas the landed aristocracy encouraged and facilitated a healthy local life as a matter of philanthropy, whether self-interested or not, the administrative aristocracy could not replicate these conditions and feared their natural replacement-local associations. As Tocqueville argues in Democracy in America, it is in local associations that the structures of charity and local life are reborn in democracies; associations attend to some of the daily needs of citizens and obviate the need for centralized administrationalways a threat to local liberties $(D A, 88)$. 
In sum, for Tocqueville the administrative aristocracy failed because it cannot be philanthropic. An administration might administer aid, but it does not do so from any sense of fellow feeling, long-standing tradition, or devotion. Moreover, an administrative aristocracy cannot be a moral exemplar. More often than not, a bureaucrat's obligation is to the job description and the paycheck, not to people. Unlike the noblesse, Tocqueville seriously doubts that an administrative aristocracy can participate in the shared history of a particular people in a particular place, which is the very fount of those bonds of affection that lie at the heart of both charity and elite philanthropy.

\section{Administrative Dysfunction in England}

Whereas the effort to compensate for the disaggregation of elite power and responsibility was still nascent in France, for Tocqueville centralized administration was more developed in England. After making a trip there in 1833, he wrote his Memoir on Pauperism to highlight the difficulty of shifting the philanthropic obligations of the local noblesse onto the state. In other words, in the Memoir, Tocqueville is asking, "What might be the consequences of trying to recreate the virtues of the nobility in an administrative class?" His answer is that administrative aristocracy is necessary in an emerging commercial and democratic society, but it cannot fully replace local philanthropy. No matter its failures or successes, it is nevertheless incumbent on the most privileged to live up to their philanthropical obligations.

Tocqueville points to an event in English history that parallels the events that gave rise to the administrative aristocracy in France. The religious revolution begotten by Henry VIII "changed the face of England, [because] almost all the charitable foundations of the kingdom were suppressed" $(M P, 26)$. In former times, in both France and England, care for the poor was undertaken by both the local nobility and the church, which were basically two sides of the same coin. In France, the damage was done by the evisceration of the nobility, as we have seen. In England, it was the evisceration of the church. When Henry VIII dispossessed the Catholic Church, "their wealth became the possession of the nobles and was not at all distributed among the common people.... The poor remained as numerous as before while the means of providing for them were partly destroyed" $(M P, 26)$. In other words, the double-pronged sources of philanthropy - moral sentiment and wealth-were separated. The poor were left to their own devices.

Charitable obligations were fulfilled neither by the church, the landed noblesse, nor the newly emerging industrial aristocracy. Thus, as in France, as poverty spread, the English Crown created an administrative aristocracy to fill the void. This administrative aristocracy was governed by the famous Poor Law. Tocqueville refers to the activities of the English administrative 
aristocracy as "legal charity" (la charité légale), which is contrasted with the virtue of individual charity (la chariteé individuelle). ${ }^{27}$ His words here are telling:

There are two kinds of welfare [bienfaisances]. One leads each individual, according to his means, to alleviate the evils he sees around him. This type is as old as the world; it began with human misfortune. Christianity made a divine virtue of it, and called it charity. The other, less instinctive, more reasoned, less emotional, and often more powerful, leads society to concern itself with the misfortunes of its members and is ready systematically to alleviate their sufferings. (MP, 25-26)

In other words, whereas legal charity is more powerful and systematic, private charity emerges from fellow-feeling. ${ }^{28}$ It is incorporated; it emerges from shared suffering or, in its Latin form, com-passion-i.e., "to suffer with." When one feels the suffering of another, one experiences compassion. Private charity is precisely this kind of incorporated sentiment. Public charity, or social welfare, is based on rationality, and therefore is, by definition, less affective.

It is precisely because legal charity is calculated, systematic, and abstract that Tocqueville thinks it can benefit from elite philanthropy. In England, for example, the poor were divided into two groups: the able-bodied and the infirm. Administrators determined systematically who would receive welfare (bienfaisances) gratis, and who had to work for it. The problem is that this cannot be done systematically; administrators are human beings and thus subject to compassion. As Tocqueville puts it,

Nothing is so difficult to distinguish as the nuances which separate unmerited misfortune from an adversity produced by vice. How many miseries are simultaneously the result of both these causes! What profound knowledge must be presumed about the character of each man and of the circumstances in which he has lived, what knowledge, what sharp discernment, what cold and inexorable reason! Where will you find the magistrate who will have the conscience, the time, the talent, the means of devoting himself to such an examination? Who would dare to let a poor man die of hunger because it's his own fault that he is dying? (MP, 28-29)

The effort to distribute welfare locally is good, yet, as legal charity, it is supposed to be systematically disbursed. When administered systematically,

${ }^{27}$ Alan Kahan, Alexis de Tocqueville (New York: Bloomsbury Academic, 2013), argues that Tocqueville distinguishes three kinds of charity: legal, private, and public. Public charity solves the problems with both private and legal charity by functioning as a safety net (95).

${ }^{28}$ This legal charity echoes Jeremy Beer's definition of modern philanthropy. Jeremy Beer, The Philanthropic Revolution: An Alternative History of American Charity (Philadelphia: University of Pennsylvania Press, 2015). 
however, welfare benefits (bienfaisances) are necessarily dissociated from the character of the recipients because the administrator, when face-to-face with a suppliant, is unlikely to treat him abstractly. Natural pity forbids distinctions that ensure benefits are given only to the "deserving." Poverty, Tocqueville says, can be verified, but the causes will always remain uncertain $(M P, 29)$. As a result, few are denied and, in England, this means that the Poor Law and relief "reaches a sixth, some say a quarter, of the total population" $(M P, 29)$. In Tocqueville's reckoning, this is a much higher number than it ought to be. ${ }^{29}$

Yet the problem is not just one of numbers. Legal charity also undermines virtue, for both the poor being helped and the rich whose philanthropy it replaces $(M P, 36)$. For the poor, Tocqueville suggests legal charity might be enervating and often curtails personal liberties. However, legal charity is even more detrimental to the virtues of the most privileged. For example, Tocqueville tells the story of a well-to-do merchant whose son is presumably lost at sea. The son has left a pregnant wife behind who must appeal for bienfaisances because the merchant refuses to support her. The justices adjudicating the case summon the man, and Tocqueville describes the court scene: "[the rich man] refuses to fulfill the duties imposed on him by nature and not by law. The judges insist. They try to create remorse or compassion in this man's egoistic soul. Their efforts fail, and the parish is sentenced to pay the requested relief" $(M P, 34)$. The case is of especial note to Tocqueville because the problem with charity administered by the state usually pertains to things political. That is, in familial relationships it is not difficult to imagine natural compassion. That a father will provide for his children is usually a given. That a grandfather cares for his unborn grandchild is usually a given. We care for family because it emerges naturally. It is with things political, say, between neighbor and neighbor, that one must stretch the imagination to experience the call of charity. Why a rich man would be charitable towards a tenant or neighbor is a mystery -it is, after all, not in his interest to do so. Tocqueville's argument is that administrative aristocracy obviates the call of natural compassion - in this case, even a rich man need not care for his own progeny. The Poor Law, it seems, in exonerating the most privileged from their obligations, undermines their traditional virtues. Rather than natural compassion and charity, their guiding principle is mere selfinterest, and this "interest silences the cry of shame within him and he unloads a debt on the public that he alone ought to discharge" $(M P, 35)$.

\footnotetext{
${ }^{29}$ Tocqueville's statistics were exaggerated, as many poor received no relief. However, Tocqueville's data was in line with the research of his time. As Himmelfarb explains: "We now know that the figure of one-sixth of the population on relief was much exaggerated. Contemporaries, however, did not know that, and it is useful to be reminded that the metaphor of the 'sunken sixth' represented the best-informed opinion of his time." Gertrude Himmelfarb, The Idea of Poverty: England in the Early Industrial Age (New York: Knopf, 1983), 152.
} 
For Tocqueville, legal charity does the most harm in political relations. On his account, in a flourishing aristocracy welfare (bienfaisances) is private and particular. That is to say, a rich man, having his compassion stirred by the suffering of another, gives alms. "Individual alms-giving," Tocqueville says, "established valuable ties [des liens précieux] between the rich and poor. The deed itself involves the giver in the fate of the one whose poverty he has undertaken to alleviate. The latter, supported by aid which he had no right to demand and which he may have had no hope of getting, feels inspired by gratitude" (MP, 31). In other words, it matters that the sharing between giver and receiver is concrete and face-to-face. As he puts it in Democracy in America, "Feelings and ideas are renewed, the heart enlarged, and the understanding developed only by the reciprocal action of men one upon another" (DA, 515). It is only in the face-to-face that "precious bonds" (liens précieux) are created. And it is with individual alms-giving that "a moral tie [un lien moral] is established between those two classes whose interests and passions so often conspire to separate them from each other, and although divided by circumstance they are willingly reconciled" $(M P, 31)$. And it is precisely with regard to this reconciliation of difference that legal charity does its greatest harm.

Thus, while an administrative aristocracy is necessary to alleviate some of the physical suffering of the worst-off, the moral bonds of the community itself might be undermined. For Tocqueville, charity without morality is charity without spirit. "Public alms," he says, "guarantee life, but do not make it happier or more comfortable than individual alms-giving" ( $M P$, 31). The administrative aristocracy, therefore, has the right intentions - to relieve the suffering of the poor-but it is, by its very nature, restrained to the service of mere life. Its work, though deeply good in this regard, struggles to satisfy the other two components of elite philanthropy that Tocqueville outlines in the Old Regime-providing a moral exemplar and safeguarding local liberties. Just as privilege without virtue undermines the relations between classes, so too might legal charity.

\section{Industrial Aristocracy in America}

In America, Tocqueville saw a new kind of aristocracy, but did not see the elite fulfilling the philanthropic obligations commensurate with their privilege and power. Whereas Tocqueville witnessed administrative aristocracies in France and England struggling to fill the vacuum left by the elite, in America he discovered free, local associations fulfilling the charitable obligations that once fell to the nobility. This is not to say Jacksonian America was fully democratic. In fact, Tocqueville uncovered remnants of aristocratic inequality in the slave-owning South $(D A, 375-76)$, the native peoples $(D A, 328)$, the legal profession $(D A$, 264), and finally, in the business world. It is with the latter that Tocqueville is concerned-in the United States, he observed a new elite he calls an industrial aristocracy (l'aristocratie manufacturière) or a business aristocracy (l'aristocratie que fonde 
le négoce) (DA, 557-58). He is clear regarding this concern: "friends of democracy should keep their eyes fixed [on this manufacturing aristocracy]. For if ever again permanent inequality of conditions and aristocracy make their way into the world, it will have been by that door that they entered" $(D A, 558)$.

What is the problem with an industrial aristocracy? As outlined above, when power and responsibility are joined, a philanthropic elite will safeguard local liberty, serve as a moral exemplar, and provide local services. The problem with an industrial aristocracy is that it is predicated on the unmitigated pursuit of wealth, or base self-interest. For Tocqueville, this frame of mind necessarily separates power and responsibility, which may lead to a neglect of the three components of philanthropy.

First, Tocqueville suspects that the industrial aristocrat not only fails to safeguard the liberties of his workers, he threatens them in two ways. In a discussion likely inspired by Adam Smith's Wealth of Nations, Tocqueville suggests that a person working under the logic of modern manufacturing may have his very humanity diminished. As he writes, "When a workman is constantly and exclusively engaged in making one object, he ends by performing this work with singular dexterity. But at the same time, he loses the general faculty of applying his mind to the way he is working. Every day he becomes more adroit and less industrious, and one may say that in his case the man is degraded as the workman improves" $(D A, 556)$. In other words, the repetitive tasks of industry and business create a fixity of mental habits. Focusing on a singular task narrows the imagination and stultifies the worker's ability to think new things and new ideas - that is, to be "industrious." For Tocqueville, this means the individual is removed from the grand thrust of Western history-the perfection of man-which is the engine advancing human liberty $(D A, 452)$.

The second threat to the worker's liberty is economic. Industrial manufacturing requires not just liquid assets, but also a kind of personal liquidity. To participate fully in industry, one must be willing and able to move. In modern parlance, this is called labor mobility. The division of labor limits one's possibilities in this regard. As Tocqueville puts it, "An industrial theory stronger than morality or law ties him to a trade, and often to a place, which he cannot leave. He has been assigned a certain position in society which he cannot quit. In the midst of universal movement, he is stuck immobile" $(D A, 556)$. The skills learned in a factory are often particular to one factory. There is a modicum of irony here because if one keeps in mind that for Tocqueville aristocracies offer a salubrious stability, from the democratic vantage such stability acquires pejoratives like immobility, illiquidity, stagnation, unfreedom. A manufacturing life frees the worker from a stable, yet unequal, life on an estate, but binds him to a new situation. In other words, one can be stable and free or stable and unfree. Tocqueville, obviously, prefers the former and sees the latter as a great threat in democratic times.

In this vein, Tocqueville suspects that industrial aristocrats fail as moral exemplars because they are not a class, properly speaking. A class recognizes 
in themselves certain commonalities and responsibilities. For Tocqueville, even the administrative aristocracy in France was a kind of class because it had its own "traditions, virtues, honors, [and] its own pride" (OR, 139). Likewise, the nobility competed with one another for these honors and thereby held each other to standards that, altruistically or otherwise, prompted them to public service. The industrial aristocracy, however, is not a class because "although there are rich men, a class of the rich does not exist at all, for these rich men have neither corporate spirit nor objects in common, neither common traditions nor hopes. There are limbs, then, but no body" (DA, 557). Because the business elite is not a class, it is difficult for them to behave according to the standards of a privileged elite-that is to say, there can be no true link among the rich and "they are not forever fixed, one close to the other." The only thing that holds them together is interest, and just as interest brought them together, it will pull them apart. They compete to increase their bottom line, but feel little desire for recognition for service to their workers and neighbors, never mind the least advantaged.

Finally, Tocqueville suspects that industrial aristocrats neither maintain their local communities nor attend to the welfare of the people within them. Investment in and care for a local community develop over long periods of time. With an industrial aristocracy, there is seldom this time. As Tocqueville suggests, although "poor men have few means of escaping from their condition and becoming rich ... the rich are constantly becoming poor or retiring from business when they have realized their profits" (DA, 557). In democracies, the rich fear losing their wealth, so they focus on preserving their livelihoods instead of cultivating the social obligations that disciplined feudal lords. As Sheldon Wolin summarizes, "the opportunities for social mobility had conspired to make America a society perpetually in movement and continually changing. Americans were always changing laws, jobs, locations, tastes, beliefs, and status, not once but several times." ${ }^{\prime 30}$ As Tocqueville says of masters and servants in democracies, "The servant may at any time become the master, and he wants to do so. So the servant is not a different type of man from the master" (DA, 576). Nor, indeed, does the master cultivate distinct virtues.

Furthermore, when the rich come and go there is little time for fellow-feeling or a deep commitment to a local place to emerge. Without this, philanthropic relations have insufficient time to develop. Rather than caring for a particular place, they will be experienced as abstractions. In Tocqueville's language, "the workman is dependent on masters in general, but not on a particular master. These two men see each other at the factory but do not know each other otherwise, and though there is one point of contact, in all other respects they stand far apart. The industrialist asks the workman only for his work, and the latter only

\footnotetext{
${ }^{30}$ Sheldon S. Wolin, The Presence of the Past (Baltimore, MD: Johns Hopkins University Press, 1990).
} 
asks him for his pay" $(D A, 557)$. The problem with such abstractions is that they open the way to treating other human beings as mere ideas or tools, rather than unique individuals with whom one experiences all the duties and obligations of a decent community. Such abstractions, Tocqueville tells us elsewhere, would have been all but impossible for his ancestors (DA, 481-82).

The distinction between this new aristocracy and the old is stark. As Tocqueville puts it, "the territorial aristocracy of past ages was obliged by law, or thought itself obliged by custom, to come to the help of its servants and relieve their distress. But the industrial aristocracy of our day, when it has impoverished and brutalized the men it uses, abandons them in time of crisis to public charity to feed them" (DA, 557-58). Like the well-to-do merchant refusing to support his daughter-in-law, the business aristocrat, uninspired by concrete connections, might only be compelled to philanthropy by law. It is thus that Tocqueville thinks a full-blown industrial aristocracy can be "a monstrosity" $(D A, 557)$. When relations are temporary, predicated on base self-interest and physical abstractions, the result can be disastrousnobody will care about the welfare of anybody but themselves. Should an industrial aristocracy, devoid of the virtue most appropriate to privilege, dominate social and political life, there will be no safeguarding of local liberties, no need to serve as moral exemplars, and no obligation to serve a local community - it would be all power and privilege and no responsibility. The egoism, or base self-interest, that informs this way of life will separate man from man and ultimately undermine the very basis of free and equal community.

\section{Disciplining the Rich}

\section{A Moral Metric of Virtue}

If the abstractions of industrial aristocracy were unimaginable for Tocqueville's ancestors, the nature of today's business aristocracy would be unthinkable. The Wall Street hedge fund manager, who daily commutes by helicopter from the Hamptons, is not only physically removed from average citizens, the very nature of his enterprise is abstract. Whereas the "territorial aristocrat" of the thirteenth century administered an agricultural estate, a hedge fund manager daily swaps billions of dollars of mortgagebacked securities, each of which contains bits of tranched properties, the occupants of which will never be known, let alone cared for.

We have argued that for Tocqueville, the virtue most appropriate to the privileged elite is a particular kind of charity we have called philanthropy. To be philanthropic means to be a moral leader, to safeguard local liberty, and to maintain one's local community-usually through financial means. What, then, might we say about the business and industrial elite today? Do the superrich embody the virtue most appropriate to their class? Are they philanthropic, according to the measure Tocqueville suggests? In 2019, for 
example, Americans donated nearly $\$ 450$ billion to charities. ${ }^{31}$ The wealthiest Americans give staggering lumps of money to myriad causes, as documented by The Chronicle of Philanthropy. ${ }^{32}$

Our purpose here is to provide a framework for thinking about the superrich in America today. For example, even if the superrich generously fill art museums and install their names on university buildings, are they philanthropic according to the Tocquevillean metric? Do these efforts provide moral leadership? Safeguard liberties? Build particular communities? To satisfy these demands, philanthropy must be concrete. Both moral leadership and the safeguarding of local liberties imply a kind of proximity between giver and recipient. The billions of dollars that, for example, the Gates Foundation, the Walton Family Foundation, the Broad Art Foundation, and the Koch Foundation give to hospitals, universities, churches, museums, parks, and so on are from identifiable people and families to concrete and identifiable communities. However, as we can infer from the OWS movement and scholars like Jeffrey Green, these philanthropic efforts may be so inconspicuous that they fail to provide the moral leadership Tocqueville considers a central part of the virtue.

Somewhat more difficult to assess from this theory of philanthropy is the safeguarding of liberty. In the feudal age, the local lord could stand firm in the face of royal overreach and foreign invasion, but what might this mean in our age? In this case, one might imagine a foundation established to provide decent legal representation for the least privileged-who also happen to be most in need of decent representation. One might imagine "philanthrolocalism," as Beer describes, such as scholarships for students to attend local public universities. ${ }^{33}$ Education is nothing if not liberating. Whatever we might suggest here, one might also keep in mind that while giving money is always a good for Tocqueville, it does not exonerate the most privileged and powerful from actual public service. Participation in civic life is central to the preservation of democratic liberty, and from those with much, more service is to be expected.

\section{Disciplining the Rich}

How might the rich become more philanthropic, as Tocqueville describesthat is, fulfill their duties to their neighbors in proportion to their power and privilege? Feudalism is dead and, as Tocqueville knows well, "the age of blind sacrifice and instinctive virtue is already long past" $(D A, 528)$. A "sublime conception of the duties of man" no longer pertains to the

${ }^{31}$ According to Giving USA (see http://givingusa.org, accessed April 1, 2021). For more on the history and current state of philanthropy in America, see O. Zunz, Philanthropy in America: A History (Princeton: Princeton University Press, 2012).

${ }^{32}$ See https://philanthropy.com.

${ }^{33}$ Beer, Philanthropic Revolution, chap. 4. 
democratic age $(D A, 525)$. Instead, we are left with a secular and immanent version of this virtue-the doctrine of self-interest properly understood. Though some view the Tocqueville of volume 2 of Democracy as pessimistic about the future of democracy, it is here that he suggests an antidote. Selfinterest is the way "Americans combat individualism." And while he is most likely referring to the middle class in these passages, there is no reason that the principle cannot be brought to bear for the most privileged. Tocqueville marvels at this doctrine not only because it connects interest and duty, but because it does not arise ex nihilo. There is thus a need to discipline this virtue into practice-for this virtue to be realized in democratic times, it is necessary to connect purposefully and explicitly self-interest to philanthropic efforts. Only then can we expect to "reopen the hearts of the rich" (OR, 188).

It is, however, one thing to extol a virtue but quite another to actualize it. One can proselytize ad nauseam about expanded public service, civic engagement, local liberties, and so on, but it is quite another thing to discipline a Wall Street "Bankster" to be philanthropic. There is, however, a relationship between policy and citizen virtue that is well-established in the scholarly literature. Suzanne Mettler, for instance, has demonstrated that the G. I. Bill gave rise to the so-called Greatest Generation. ${ }^{34}$ Others have established that policy can make citizens better or worse. ${ }^{35}$ Avramenko and Boyd suggest a set of policy recommendations to encourage middle class virtues. ${ }^{36}$ In other words, it is possible to tweak public policy such that it moves citizens - be it the middle class or the privileged elite-towards a certain set of virtues. There are, of course, those who think it is impermissible for the state to endeavor this. Tocqueville, however, is not one. As he puts it, "From the moment when the rich classes no longer have a direct and permanent interest and a strict duty to come to the aid of the poor classes, and preserve them from the most extreme hardships, it is necessary that the law force them to do so" $(O R, 378)$. We are not arguing that the law should force philanthropy, but rather that policies inevitably encourage certain practices and habits of the heart. Tax deductions that incentivize local charities, scholarships, and the fostering of local association, or prizes for public service, such

\footnotetext{
${ }^{34}$ Suzanne Mettler, "Bringing the State Back into Civic Engagement: Policy Feedback Effects of the G. I. Bill for World War II Veterans," American Political Science Review 96, no. 2 (2002): 351-65.

${ }^{35}$ Theda Skocpol, Protecting Soldiers and Mothers: The Political Origins of Social Policy in the United States (Cambridge, MA: Belknap Press of Harvard University Press, 1992); Joe Soss, "Lessons of Welfare: Policy Design, Political Learning, and Political Action," American Political Science Review 93, no. 2 (1999): 363-80; Andrea Louise Campbell, How Policies Make Citizens: Senior Political Activism and the American Welfare State (Princeton: Princeton University Press, 2003).

${ }^{36}$ Avramenko and Boyd, "Subprime Virtues."
} 
as presidential medals or throwing out the first pitch at baseball games, all might encourage something of an honor-based philanthropy.

In recognizing that we have a privileged class of superrich in America, and by gesturing to a virtue most appropriate to this class, we are not suggesting philanthropy replace legal charity or welfare. Instead, our aim is to draw from Tocqueville the idea that as long as we have a privileged class, we ought to be steadfast in our reasonable assessment of their actions. Hence, the purpose of this article is to provide a moral metric by which to judge the philanthropic efforts of the most privileged. If these efforts fall short of maintaining communities, safeguarding local liberty, and providing moral exemplars, perhaps policy can nudge the most privileged to a kind of philanthropy that accords with a Tocquevillean view. 